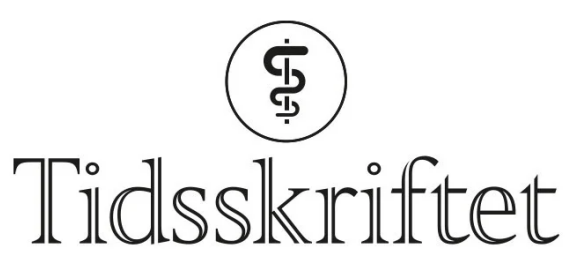

DEN NORSKE LEGEFORENING

\title{
Medisin og dannelse
}

\author{
ANMELDELSER
}

TROND TRATTEBERG SERKLAND

Fastlege, Bønes Legesenter

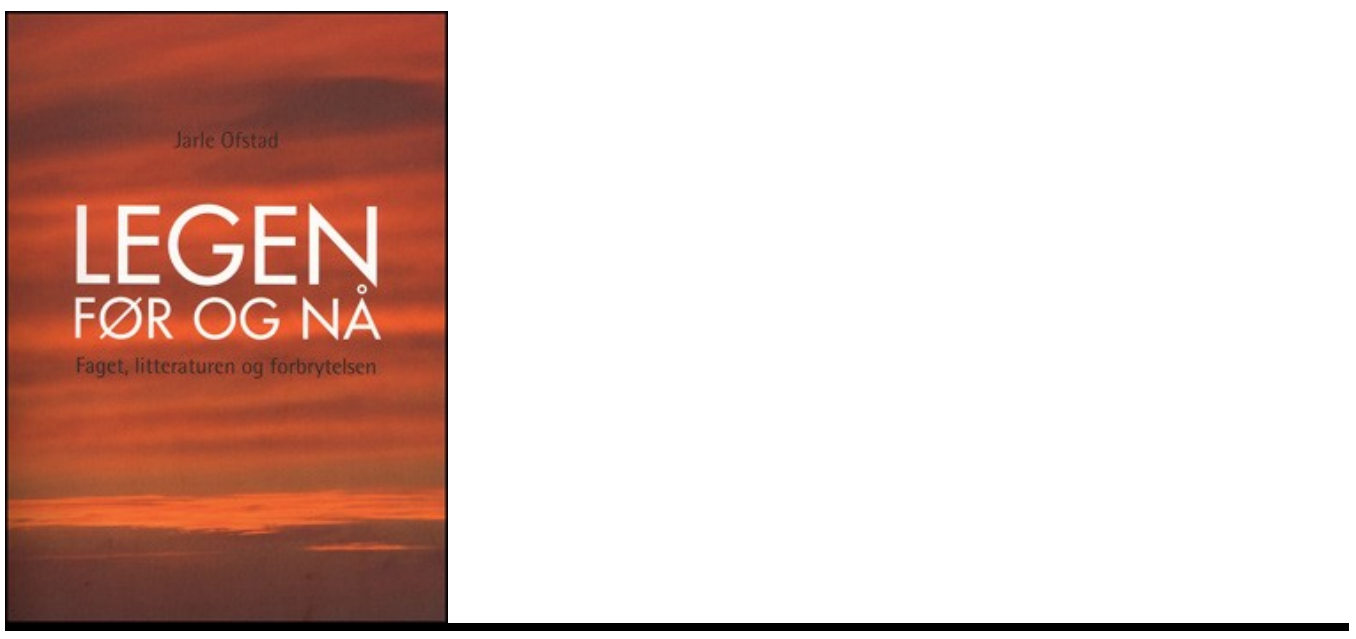

Ofstad, Jarle

Legen før og nå

Faget, litteraturen og forbrytelsen. 432 s, tab. Oslo: Arneberg Forlag, 2014. Pris NOK 349

ISBN 978-82-8220-072-1

Jarle Ofstad er pensjonert overlege i nefrologi og professor emeritus ved Universitet i Bergen. Han skriver i forordet til Legen før og nå: "Jeg var 79 da mitt siste bidrag til vitenskapen kom på trykk, og tenkte det var fornuftig å bruke mine siste tilmålte dager til noe annet enn å holde seg faglig à jour og likevel gå nedover bakke.» Resultatet er denne boken, og Ofstad har brukt dagene godt. Se forbi omslaget, tittelen og baksideteksten: boken er svært interessant.

Den består av tre deler, som hver utgjør et essay på rundt 150 sider. Del 1 omhandler legenes plass i historien, fra skikkelsene rundt Hippokrates og frem til vår tid. I del 2 tar Ofstad for seg leger som opptrer i skjønnlitteratur, både som forfattere og karakterer. I den tredje delen, «Forbrytelsen», ligger hovedvekten på legenes rolle i Nazi-Tyskland. 
Både emnene og måten de legges frem på, er engasjerende. Teksten bærer preg av å være skrevet av en inspirert forfatter med stort overskudd. Den er spekket med sitater og "énlinjere» som: «En logisk tankerekke på mer enn tre ledd er som regel gal», eller «Å forstå det man leser, er ikke det samme som å skjønne hva det betyr». Målet synes å være å bidra til et dannelsens bakteppe til faget og utøvelsen av det. Jeg mener forfatteren her leverer et viktig bidrag.

Når det er sagt, er det er ikke alltid lett for en ung mann å følge Ofstads referanser. Partier av teksten preges av en utstrakt «name dropping», og han forventer at leseren behersker både tysk og fransk. Tekstene som nevnes, tilhører stort sett et klassisk repertoar, og nålevende forfattere som omtaler leger (f.eks. Michel Houellebecqs viktige bidrag) er i all hovedsak forbigått.

Mest interessant er det når Ofstads konkrete tenkemåte som lege og medisiner kommer frem og brytes opp mot historikerens og litteraturviterens. Det er en sjelden tyngde og dybde i disse passasjene; som leser er jeg takknemlig for å bli tatt med inn i perspektivene han presenterer. Boken er svært relevant for leger og medisinstudenter, men også for alle som er interessert i det underlige fenomenet medisin og utøvelsen av medisin er.

Publisert: 5. august 2014. Tidsskr Nor Legeforen. DOI: 10.4045/tidsskr.14.0662

(C) Tidsskrift for Den norske legeforening 2023. Lastet ned fra tidsskriftet.no 26. april 2023. 